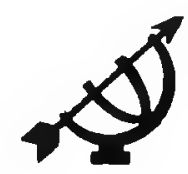

\title{
Understanding the concept of land in the Old and New Testament: The importance of a personal factor
}

\author{
J.L. Helberg \\ School of Biblical Sciences and Biblical Languages \\ Potchefstroom University for CHE \\ POTCHEFSTROOM
}

\begin{abstract}
Understanding the concepl of land in the Old and New Testament: the importance of a personal factor

Since the early times of the calling of the patriarch Abraham, the land of Israel had a very important place in the Old Testament. Some say that the concept of land was "Christified" in the New Testament era and has since lost its importance. Others regard this approach as spiritualising and stress the sociological importance of the concept of land in the Old and New Testament. Some interpreters even advocate a theology of ecology. This article points out the important place of the personal factor with regard to land in the Old Testament and attempts to indicate how this line of thought also pervades the New Testament. It is only when this factor is borne in mind, that the theologian and preacher can see the different aspects of the concept of land in their true relation to each other.
\end{abstract}

\section{Introduction}

Since the early times of the calling of the patriarch Abraham, the land of Israel had a very important place in the Old Testament. Olivier (1996:250) states that the very fibre of the Old Testament is couched in spatial terms. According to Weinfeld (1993:xv) the fate of the land is the focal point of Biblical historiography. Rendtorff (1975:23) regards the concept of land as so important that he finds it strange that no land theology has been developed. Some say that the concept of land lost its importance in the New Testament era (for various approaches and for detailed discussion of these and other relevant matters cf. Helberg, 1990a). According to Davies $(1974: 213,220)$ the concept of land was "Christified" in the New Testament era. Others, like Brueggemann (1978:185 ff), regard this approach as spiritualising and stress the sociological importance of 
land in the Old and New Testament. Other interpreters even advocate a theology of ecology. According to Santmire (1985:189-199) the position of man was too central in Christian theology in the past, whilst the rest of the animate and inanimate world was merely seen as a kind of backdrop to the drama of human history in the Old Testament. Nature is presently high up on the agenda of the World Council of Churches. The WCC meeting in Canberra especially embodied the efforts of the WCC to focus on creation in totality and to found it theologically; thence the theme "Come, Holy Spirit - renew the whole creation" (cf. Castro, 1991:1-3). Some of the contributions delivered at this meeting gave rise to controversy concerning a kind of identification of the work of the Spirit and the cosmos (cf. various other articles in The Ecumenical Review, 1991 as well as in International Review of Mission, 1991, especially that of Fitzgerald, p. 319-320).

This article points out the important place of the personal factor with regard to the concept of land in the Old Testament and attempts to indicate how this line of thought also pervades the New Testament. Only when this factor is kept in mind, theologian and preacher can have an eye for the importance of the aspects pointed out above and see them in their true relation to each other.

The Old Testament sees God as personal. This view is in contrast with that of the Canaanite religions and other contemporary religions in which the gods were in fact deified forces of nature, and to African religions, which also make a close link between the deity and these forces. The Old Testament view is also in contrast to the modem secular view of nature in which there is little room for a personal Creator and Sustainer of the world. The Old Testament revelation is so personally dominated that Jesus regards the divine self-identification "I am the God of Abraham, Isaac and Jacob" as proof of an unbreakable personal relation, and therefore of the resurrection (Mat. 22:31-32). This personal character thus does not spiritualise man and his needs but guarantees bodily resurrection. Jesus further summarises Old Testament teaching by referring to this personal relation: to love God and one's neighbour (Mat. 22:37-40). This personal factor does not negate one's relation to nature but encompasses it, as will be shown below.

\section{Land in the Old Testament}

\subsection{Creation/Creator}

God is not only the almighty Creator, but also a personal Creator (cf. also Helberg, 1988:48-62), as is obvious from the refrain "and He said" at the creation of heaven and earth (Gen. 1). Man was created in God's image (Genl. 1:26-28), implying, inter alia, a relation like that of child and father (Gen $5: 1-3)$. $\wedge$ natural relation is, however, excluded, as God is the Creator and man the creature Man also has a close relation with creation; immediately after (iod lad created man. He saw not only man, but "all that He had made", and II was wer gond III his eve 
(Gen. 1:31). Man is seen by God not in isolation, but "holistically" and as responsible toward God for maintaining creation (cf. God's summons to "rule", Gen. 1:28). According to the account of man's creation in Genesis 2 a close relation exists between man and the earth (soil, 'dmh) - man was made from the soil, but he was simultaneously elevated above the earth/soil because God "breathed into his nostrils the breath of life" (Gen. 2, 7; cf. also Ps. 8). This event also testifies to an intimate personal relation between God and man. This fact is further reflected by the fact that in the Old Testament God is never called the God of a place, like "the God of Sinai" or "the God of Jerusalem". (In 2 Kings 17:26 ff.; 18:34 ff.; 2 Chron. 32:19 heathen are speaking; and in Gen. 31:13 [ha'el bêt'el] corruption of the text is obvious; cf. van Selms, 1967:116.) God is, however, called the God of people (Abraham, Isaac, Jacob, Israel; Gen. 28:13, Ex. 3:16; 2 Sam. 7:25-26). The Creator is not geographically limited, as in the case of the gods of Israel's contemporaries (cf. e.g. Baal Hazor, 2 Sam. 13:23; Baal Hermon, Judg. 3:3), though He has a special relation with his elected covenant people Accordingly, the expression "you are my people" occurs much more frequently than "the land is mine" or similar expressions (cf. Martens, 1972:319).

Because God is the Creator, Israel could persevere in hope even in hopeless situations; God can do what is impossible according to human standards. He has life-creating power and can fundamentally change fatal circumstances (Ezek. 37:4ff, 12-14) and even the hard hearts of men (Isa. 51:7; Jer. 31:31-34; Ezek 36:24-28). As Creator He has to do with his own creation; He does not desert the works of his hands. He will reveal and prove himself as Jahweh by bringing back his exiled people to their land and care for them within this land (Ezek. 37:13-14; Isa. 57:13). The land is then regarded not so much as Lebensraum for his people than instrument of his revelation: to show that He is Jahweh (cf. Martens, 1972:351-354). As Creator, the needs of his people concern him (Isa. 40:27), especially those of the poor and needy (Isa. 58:7; Jer. 22:16). He is not an impersonal Creator but has a personal relation with people (cf. also Blenkinsopp, 1986:366). His word is effective and includes redemption (Isa. 55:6 ff.). His capacity as Creator is closely linked with love and mercy (Isa. 62:2 ff.; Jer. 33:2, 11; Ezek. 30:25, 29 cf. 37:14, Lam. 3:22-42). His mercy for his people is as unfathomable as the heavens and the foundations of the earth (Jer. 31:35-37; 33:19-26). The return from exile is not merely a national event, but part of God's demonstration of his power as Creator and his universal rule. Therefore it envisages the welfare of all nations (Isa. 42:6; 49:6).

\subsection{The garden of Eden}

Man was "put" in the Garden of Eden by God (Gen. 2:15). Neither a mere natural nor an automatic link exists between man and his dwelling-place, nor was man born there. (Similarly lsrael as a people was not bom in the promised land, $\mathrm{cf}$. 
Understanding the concept of land in the Old and New Testament ...

below.) Man's dwelling-place is determined by his relation to God who breathed the breath of life into his nostrils. Man was put into the garden, a place which he could manage and of which he could take care. Genesis 1 and 2 read as a unit thus teach that man was given a local as well as a universal task (Gen. 1:28; $2: 15$ ). This task is not only collective but individual; God dealt with the other creatures as groups (cf. the refrain "according to their kinds"), but man was created an individual, or a pair (Gen. 1:27), Adam and Eve (Gen. 2:22-23).

Man strove to be autonomous and to make decisions on his own, without God. He tried to gain knowledge from a tree as such. This a-personal attitude and action caused a breach with God as well as with creation (Gen. 3:17). Man was expelled from the garden: an alien to God and his creation, though he also received a token of God's grace in that God clothed him (Gen. 3:21) and upheld his rule over creation (Gen. 9:2-3). Man thus has an ambivalent relation with God as well as with creation. The former is reflected in the psalmist's expression "I dwell with you as an alien/stranger" (Ps. 39:11-12; 119:19), in which not only his alienation is expressed but also his trust in God's care for him as alien (Lev. 19:33-34)

\subsection{The patriarchs}

Abraham was promised a land, a symbol of the garden of Eden from which man was driven, where man could enjoy the fruit of the earth in peace by working and sustaining it in the presence of God and keeping his commandments (Gen. 12:1-3; 26:3-5). Thus the land (nor any other land) was not (nor is) a "creation ordinance". Neither is the land the instrument which effects this relation which it symbolises, but the result of this relation and of the space in which the relation with God can and must be practised. ${ }^{1}$ Mankind strove after unity and a name on earth by building a city with a tower: a centre of technology, trade, politics, finances, etc. (Gen. 11). There is no mention of God or the neighbour in this planning. As in the garden of Eden, mankind's effort is a-personal. God responds to this a-personal effort of mankind to accomplish unity, not by providing another city (like Jerusalem), but by calling Abraham. God provides a person as an instrument to achieve this goal ("all the peoples of the earth will be blessed through you", Gen. 12:3). This is determined by peoples' attitude towards Abraham and his God (Gen. 12:2-3). This thoroughly personal approach of affairs is also reflected in the fact that God calls himself "the God of Abraham/

Therefore the following statement of Werblowski can only be true in a relative sense "that the biblical God does not in the first place have a 'people' to whom he then provides a suitable land, but that he, universally, acts as the owner of a 'land', in which he promised to make small groups of 'clans' into a 'big people"' - quoted by H Stegemann (1983:161; cf. below) 
Isaac/Jacob" and "the God of Israel", expressions with far-reaching implications (cf. above). At the same time nations will have a part in the divine blessing.

\subsection{Election and covenant}

Abraham was elected by God for the said aim, not because of merit but because of God's sovereign grace. Abraham's genealogy was a declining one, ending with a couple who could have no children (Gen. 11:10-30). Furthermore, Abraham had to part with his land and family: the whole atmosphere in which he lived. God made a new beginning with Abraham, a new creatio ex nihilo so to speak (Van Selms, 1967:177). He also calls for a way of life according to his will. Therefore $\mathrm{He}$ enters into a special relation with Abraham, a covenant relation, which not merely implies a formal agreement but a personal relation of trust and love (Gen. 15:17). The avoidance of the term "covenant" by some prophets does not in itself imply a late origin of the concept of covenant in Israel, but testifies to Israel's formalising and distortion of this special relation, giving a bad connotation to the term. ${ }^{2}$ Israel broke their part of the covenant relation to such an extent that they were eventually exiled and had nothing to rely on before God in this situation. However, God remained true to his disloyal people. This situation required a new covenant relation, one which was not essentially different from the previous one, though, but one in which God also promised to change the Israelites' hearts, enabling them to live up to the requirements of this relation (Jer. 31:31-34).

\subsection{Exodus and settlement}

The exodus from Egypt is not immediately followed by the settlement in the promised land (similar to the history of Abraham remaining a stranger in the land), but rather by Israel's reception of the torah in which God's will and requirements for the covenant relation are expressed. ${ }^{3}$ These requirements are not cultic or ritualistic but are religious and ethical; they comprise the correct relation toward God and one's neighbour. The exodus and the torah are closely linked to one another in God's self-identification "I am Jahweh your God, who brought you out of Egypt, out of the land of slavery" (Ex. 20:2). The exodus is pivotal in

Kreuzer (1983:359) correctly states that the theme of covenant justice is essentially valid and can hardly be fully eliminated from Israel's early history Nicholson (1986:215-216) emphasises that "'covenant' is the central expression of the distinctive faith of Israel as 'the people of Yahweh', the children of God by adoption and free decision rather than by nature or necessity".

3 Cf. also Stek (1978:133-165), further Noort (1995:140) for the close connection of land and law. He sees two axes in relation to the land: From concrete to symbolic in the change from the deuteronom(ist)ic texts to the late prophets after the exile. And from the connection between conditional law, law and land with the deuteronomists to the connection between covenant and promise, the presence of God and the land of the priestly writers. 
the Old Testament and is often referred to. The idea of exodus is much more pivotal than the settlement in the land, and the latter is nowhere part of God's self-identification. As in the case of Abraham, a certain place is not emphasised, but rather the situation in which God is not served as He should be. The emphasis is on a living relation with God. This is also obvious from the introductory chapter to the giving of the torah in Exodus 19: "You yourselves have seen what I did to Egypt, and how I carried you on eagles' wings and brought you to myself" (Ex. 19:4). The goal is not so much a space to live in - the whole world in fact belongs to God - but rather that "you obey me fully and keep my covenant" so that "you will be my treasured possession" and "will be for me a kingdom of priests and a holy nation" (Ex. 19:5-6).

It is for this reason that the wandering in the wilderness (which in fact is the opposite of living in the land) can be seen by prophets as a heyday in Israel's history (Jer. 2:1 ff; 31:2; Isa. 63:10-14), and that the Rechabites' way of life could be accommodated (Jer. 35). The time of wandering in the wilderness was the time in which Israel's foundations as a people were laid: her election, the revelation of the Name of Jahweh, the covenant at Sinai, and the torah. From the aforegoing it is obvious that the scope of the Old Testament is exhausted by neither a "theology of land" (Brueggemann, 1978) nor a "theology of exile" (cf. Raitt, 1977) though the essence of both is accommodated.

We can conclude then that the issue of land in the Old Testament is not geocentric but theocentric. The same applies to the issue of who God's people are. "Israel" is essentially a notion of faith, not of nationality or of geography. "Israel" is not constituted by people who share the same nationality or the same land, but by people sharing the same faith (cf. Bächli, 1962:132; Gerleman, 1971:785; Zobel, 1982:1006-1008; Wildberger, 1982:1634-1635).

\subsection{Ownership of the land}

Israel's ownership of the land was not determined by birth (cf. above), but by their covenant relation with God. The reference to this land as "the land of Canaan" occurs much more frequently than to "the land of Israel" (cf. Ohler, 1979:58). The land was their "inheritance", an expression which does not refer to a right to the land but to a responsibility to its real Owner (Lev. 25:23-24). God made living in the land dependent on the right behaviour toward him and the neighbour. Lack of this would result in exile (Ezek. 15:8; 20:22-23; 22:7-15). Israel had to have mercy on and care for the needy in the land by keeping the year of the Jubilee, leaving grain on the lands, etc. (Lev. 23:25, 27. This condition does not imply a "redistribution of capital"; it was in fact a restoration (cf. Wright, 1990:179). The personal and the historic aspects were emphasised rather than the geocentric aspect of land as such. When bringing the sacrifices of the first fruit, Israel therefore did not thank God for the fruits of the land, but for his 
historical action of bringing them to the land (Deut. 26:1-10; cf. Wildberger, 1956:404-405; Von Rad, 1968:114). This point of departure is in contrast to Canaanite religions with their geocentric gods and festivals. Care for the needy was thus not merely founded sociologically, but theocentrically (Israel's redemption from Egypt, Lev. 19:34), and stressed responsibility, also of the needy. Israel was redeemed from slavery in order to serve God (Lev. 26:13-14) - Him only (Lev. 26:1). Similarly the land is not merely "a land flowing with milk and honey" in a geographical sense (Lev. 20:24, Jer. 11:5; Ezek. 20:6). This expression implies faith in God's care for this land (cf. Ploger, 1973:103).

\subsection{Monarchy}

Monarchy was a relatively late institution in the history of Israel. All the essential constitutive aspects of Israel as a people had already been present when Israel acquired a monarchy in the time of Samuel (1 Sam. 8). Israel was a covenant people already, with the covenant law and a land. As a matter of fact, Israel as a people was borm not while in a land, under its king or self-rule, but before and during the exodus. With David and Solomon kingship attained peak levels, but eventually it declined. Israel was disappointed with its kings, who neglected their task as representative of the divine righteousness and mercy, especially to the poor and needy and were responsible for much of Israel's hardship and even for the exile (Jer. 22). During the exile the covenant people had no king, and after that, kingship was practically done with. Israel survived the loss of kingship relatively easily. There was a growing yearning for a messianic king (Isa. 9:5-6; $11: 1-5$, Jer. 23:5-6; 30:21; Ezek. 17:23; 33:15; 34:23; 37:24), though closely linked to God's promise to David and his house (2 Sam. 7). The Old Testament even speaks of the deliverer of the covenant people as someone who is the opposite of a king, namely a suffering servant (Isa. 53). This view does not, however, imply that after the exile Israel (Judah) was not in favour of kingship (cf. Gerbrandt, 1986:189-190; Gross, 1988:131-133).

\subsection{Exile}

Israel was exiled because they did not live according to the covenant of Jahweh, including requirements concerning the land (ecological motivation, Lev. 26:34) and needy people (Jer. 22:16). Loss of the land was a fatal blow to Israel (Ezek. 37), not because of the land as such, but because it underlined the loss of their relation with God (Jer. 9:13-16; Lam. 5:21-22). As a matter of fact, the exiled group rather than those who remained in the land and boasted that they were the covenant people, was regarded by God as his people (Ezek. 11:15-16). This is why the vision of the resurrection of Israel was located in the land of exile, why it happened because of the activity of God's word and Spirit, and why the return was closely linked to the new covenant in which the people would have a new heart (Ezek. 37, 36:26). Return to the land implies a return to God, namely 
Understanding the concept of land in the Old and New Testament...

conversion (Lam. 5:21; Helberg, 1990b:381-382). In exile Israel again discovered the meaning of the individual and personal relation with God. (This fact is more important for our purpose than the (over?)statement of Terrien, 1978:390, that whilst Israel lost their holy places during the exile they discovered holy times.) The prophets Jeremiah and Ezekiel emphasise individual responsibility and conversion (Isa. 55:6-8; Jer. 31:34; Ezek. 18).

\subsection{The relation garden/land/city/temple}

The history of revelation begins with a garden, continues with a land and ends with a city (Jerusalem; and the new Jerusalem, cf. below). This is not due to different theologies, but to different stages in God's way with man (and with God's covenant people, representing mankind during the interim period between the calling of Abraham and the fulfilment of the universal promise to him.) $)^{4}$ As was shown above, the dominating factor in all these stages and situations is God's relation with man personally. Sinai never acquired an important meaning in itself and did not become a place of pilgrimage. Jerusalem did eventually acquire a very important meaning, even more than the land, but this was due to a combination of historical events under the guidance of God (cf. also Clements, 1980:77, 84, 88; Levenson, 1976:139 on the issue of the Jebusite cult). Jerusalem was sometimes described in terms of the mythological idea of the navel of the earth (Ps. 46; 48), but this was only a way of emphasising God's sovereignty over against the mythological power of the gods of the other nations. Although popular belief adhered to a theology concerning the invincibility of Jerusalem, and which was founded in mythological views, this was contrary to genuine Old Testament faith (Lam. 4:20; cf. Helberg, 1990b:378). God's love for people is greater than his bond with a certain place. The God who resides on Zion does not need to stay there. He accompanies his people into exile (Ezek. 1). He is with the exiled people rather than with those who remained in the land and boast that they, not the exiles, are the real people of God (Ezek. 11:15-16). He will allow his people to return to Jerusalem again, but the deepest ground for the yearning to return will not be the city itself, but the pervasive atmosphere as expressed in the name: "The Lord is there!" (Ezek. 48:35).

\subsection{The word of God}

God causes things to happen by his word. This had been the case since creation (Gen. 1). He merely spoke and it happened. His word is efficacious, though it

Cf also Brinkman (1992:253) on "the absence of a 'quantitive, strictly structural perspective of space' (which) may facilitate ... a flexible experience of faith"; further Levenson (1985:19-23; $137-142$ ) on the fact that God is in no way locally bound and that his presence in the temple is an aspect of his universal presence 
does not work automatically nor magically (cf. Vriezen, 1966:238). It is not an apersonal power working on its own after been spoken by God, but is continually under God's direct personal control. Return to the land is linked with Israel receiving a change of heart by God's word and receiving forgiveness (Jer. $31: 23,29-34)$. When man is unrepentant, he is brought to destruction by the word. The preaching of the word caused land loss and exile for the covenant people because of their continual refusal to meet the requirements of this preaching (Jer. 1:2-3). According to Isaiah 40:6-8 the preacher is embarrassed by the instruction to proclaim the word, because the word had a fatal effect on Israel, similar to that of hot wind on grass and flowers. (I translate "What can I cry?", not "What shall I cry?". These verses do not only refer to man's transitoriness in general, but also to that which Israel as a people, cf. v. 7, experienced historically.) The word of God is viewed here as coming from his mouth like his breath, and compared with the destructive wind in the fields. (For this close linking of breath and word, cf. Ps. 33:6: "By the word of the Lord were the heavens made, their starry host by the breath of his mouth") The embarrassment of the preacher is solved by the announcement that God himself is coming to his people. He comes as the Sovereign Lord with power, and simultaneously as the tender Shepherd (Isa. 40:9-11). He is the almighty Creator and the life-giving Sustainer and Redeemer who effects the impossible for his elect (Isa. 40:12-31). His redemption of people includes the renovation of creation, like the rivers, springs and trees in the desert (Isa. 41:17-20). The mountains and the hills share in the joy (Isa. 55:9-13).

\section{Land in the New Testament}

\subsection{The Word became man}

The tension between man and the word of God reached a climax and was simultaneously solved in Jesus Christ, the Word that became flesh, man (John 1). The incarnation testifies to the importance which material things, like body and land, have for God, but simultaneously to their relative worth in respect to Christ and to God. The Word through whom everything was made, came to that which was his own, but his own did not receive Him (John 1:3, 11). A fundamental change was necessary to heal the relation between God and his people - so fundamental that the result was a new dispensation, over against an old one. This change is embodied in the death and resurrection of Jesus Christ. He changed things fundamentally. This applies to the covenant people as well as to the land, especially its function. However, Jesus said that He had not come to abolish the law and the prophets, but to fulfil them, to bring them to their full meaning (Mat. 5:17). The land in the Old Testament was not a goal in itself but a symbol of the kindness/goodness of God, as was the garden of Eden. Jesus himself is therefore not a replacement of the land and is never called the "inheritance". Pivotal was man's living with God as his image, in obedience to God. The land and the 
Understanding the concept of land in the Old and New Testament...

people of Israel did, in the interim period, have a special meaning as instrument of God's special mercy to mankind (Gen. 12:2-3). This special function was fulfilled with the coming of Jesus Christ.

\subsection{Events at specified places}

Scripture does not merely describe the being of Jesus, but his history: events occurring at specific places. These places are not mentioned because they themselves were important; Jesus was born, not in the renowned city of Jerusalem, but in the insignificant Bethlehem. The places are mentioned because of God's fulfilment of his promises there and because of Jesus's action there (cf. Davies, 1974:252). What is important is the idea of the kingdom of God, which concentrates in Jesus Christ and is spread by him. This kingdom relativises places but also gives them meaning. Places have no meaning in themselves, but where two or three persons come together in the Name of the Lord, there $\mathrm{He}$ is with them (Mat. 18:20). In this sense places have meaning. The churches are referred to in the New Testament in the plural, according to the local places ("Galatian/ Macedonian churches", 1 Cor. 16:1; 2 Cor. 8:1; "the churches in the province of Asia", 1 Cor. 16:19). A local church is the universal church in that place (Du Plooy, 1981:94-104). Places acquire their meaning from persons (Jerusalem "the city of David") and their relation with Jesus Christ. Therefore no place is too insignificant to have real meaning when people gather there in the Name of Christ and constitute his (full) body. On the other hand, no place is so significant that the people there can claim to live in isolation. Churches have to come together for discussion of mutual interests (cf. Acts 15). The "people of God" is thus free from a geographical bondage, locally as well as universally

\subsection{The kingdom of a different kind}

The kingdom of God is not established by ordinary instruments, not by might or violence, but by self-surrender in self-defiance, by the death and resurrection of Jesus Christ. Therefore it poses other requirements to men than an ordinary kingdom. The beatitudes are a clear example of the different character and requirements of the kingdom of God (Mat. 5). The kingdom belongs to the poor in spirit, they who are aware of how dependent they are on God. The meek will inherit the dwelling place. This dwelling place is called "the land" or "the earth" (ge), but seen in eschatological light, as something of the future of which only the beginning is already in effect. It transcends the land and the ordinary earthly dispensation in their present appearance. The New Testament reader would understand this as the recreated earth in the future time of redemption. In this way the promise of the inheritance of the land makes room for the expectation of the kingdom of God (Mat. 25:34; cf. Wildberger, 1956:419-420). When Jesus says that his kingdom is not of this world (John 18:36), it refers to this transcendence of the ordinary dispensation, not to a cancellation of it, as is clear from Jesus' 


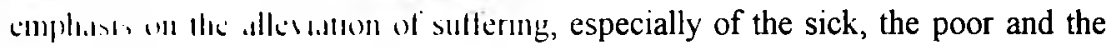
opmessed (Nul 1 23-25.61-4, 11, 8.1-17, 28-34; 9:27-34; 11:5; etc.). The people of (iod is lice belewers in every nation, tribe, people and language (Rev. 7.9) The atm is not redemption from nationhood but in the nation, contra a onesided. Individualistic concept of faith, which does not take God's creational actıvity seriously (cf. Eichrodt, 1967:254 note 2).

The transcendence of the ordinary dispensation and the consequent relativising of inter alia the land, must be taken seriously. This is also clear from the statements of Jesus and Paul about man's body after the resurrection: people will not marry then (Mat. 22:30), and the body will be as different from its state before the resurrection as the wheat from the seed which was planted (1 Cor. 15:35 ff). That which comes forth from the "seed" is not merely "harvested" by an evolutionary proses, but is "resurrected".

\subsection{Holy Supper}

The relativising of the land is also clear from the installation of the sacrament of the Lord's Supper. Jesus links this installation with the festival of the Passover (Mat. 26:17) in which Israel's birth as a people, so to speak, was celebrated (Ex. 19:5, Hos. 2:2 (MT 2:5); cf. Keil, 1949a:468; Kell, 1949b:9). Jesus then effects an important change and concentrates various lines of revelation in Himself: that of the Passover, the suffering servant of Jahweh, and the new covenant (Ex. 24:68; Mat. 26:26-27). With his blood, his death, Jesus now causes the new covenant to come into effect (Mat. 26:28), the covenant according to which God effects in men the inclination to keep his commandmends (Jer. 31:31-34; Ezek.16:59, 60; 36:26). This is what the Old Testament - the law and the prophets - is all about. Jesus summarises this in the great commandment: to love God with all one's heart, and one's neighbour as oneself (Mat. 22:37-40).

This relation, this essence of the ten commandments, is so central in the Lord's Supper that, in contrast to the Passover, no link is made with a special place. The Lord's Supper need not be celebrated in Jerusalem. It is a meal with Jesus and his believers. The relation with him and his believers dominates and relativises everything. He is the new Moses who brought the exodus to its real fulfilment. $\mathrm{He}$ redeems his people from the slavery which prevents them from serving God, especially the slavery of one's own sinful will, and He calls upon them to live according to the will of God. Jesus also brings a new perspective on the enemy. No mention is made of the external enemy, like Egypt of old or Rome of the New Testament times, but rather of the enemy within one's own circle and one's own bosom (Judas, Peter). Passover thus brings a narrowing as well as a widening of perspective. The attention is not fixed on the national identity and land, but on the individual relation between the believers and Jesus, on the personal action of remember and believe. Simultaneously there is a broadening, a universalising of 
Understanding the concept of land in the Old and New Testament ...

perspective. The Lord's Supper encompasses everyone who seeks his redemption in reconciliation with God through the body and blood of Jesus Christ. The focus shifts away from the inheritance of the land to the inheritance of the new earth (Mat. 5:5). The inheritors are only those who comply with the requirements of the kingdom of God, however (Mat. 5:3-12)

The new covenant is effected by the Holy Spirit (Ezek. 36:37). The covenant is reconfirmed by the descent and outpouring of the Spirit at Pentecost (Acts 2). In this incident land is not in the focus, or even spoken of. The Spirit is not poured out on the land, but on people; not to bind them to the land but to Jesus Christ and to each other in the fellowship of the believers. The Spirit is poured out in order to bring the believers to a new life, a life in obedience to God's commandments (cf. also Mat. 5:17). The Spirit is closely linked with the word of God, revelation, proclamation of the gospel, and therefore with hearing and understanding. Each one heard the gospel in his own native language (Acts 2:7, 11).

\subsection{Being in Christ}

Acts 17:26, which says that all nations owe their origin, survival and living place on earth to God, should be read in the light of the discussion above. The intention of this text is that every nation, in every place where God determines a living place, must seek and find the true God and convert to him. The apostle Paul makes no explicit reference to the land. He totally ignores the territorial aspect of the promise (cf. Davies, 1974:166-16, 178). The redemption is not "localised" in a place but in persons in whom grace and faith have their power. In contrast to the patriarchs, Paul does not yearn to be gathered to his forefathers. As the church among the heathen grows, the centrality of Christ as the living Lord becomes more and more normative for him. He wants to be "in Christ", "with Christ", also in death (2 Cor. 5; cf. Davies, 1974:179, 208). To form part of the posterity of Abraham and thus of God's promises, is determined by faith in Christ (Rom. 8:12-25; Gal. 3:27-29; 4:1-7). Therefore God does not have two peoples, Israel and the church, but only one People: the church, comprising the believers in Israel and in the nations (Rom. 9-11; cf. Rendtorff, 1975:20-21; Bachli, 1962: 226; Lohfink, 1981:85, 95) ${ }^{5}$ The promise to Abraham is that he will receive the earth (Rom. 4:13; cf. also Mat. 5:5). The fatherland of all believers is above (Phil. 3:20; cf. Oosterhoff, 1973:39-40). This does not de-materialise and spiritualise the promises, but it emphasises what the real and decisive factor is: Christ, and the relation with him, He who is in heaven whence He shall come as Redeemer (cf. also Hebr. 4:1-11;11:9, 16). 


\section{6 "Our Father"}

From the above it is clear that the concept of land has an eschatological meaning. The issue is not merely a geographical land or earth, but the "redeemed" earth of the future dispensation, which neither the eye did see nor the ear did perceive. The fulfilment in Christ is only the beginning of the fulfilment, the final fulfilment being at the time of his next coming. Everything focuses on Christ and his coming, He who points to God, the Almighty.

This focus is obvious from the prayer which Jesus taught his disciples. From its beginning to its end this prayer is concerned with the sovereignty of God and the acknowledgement thereof - sovereignty of the almighty God who is in heaven and simultaneously with his believers in his fatherly love ("Our Father who art in heaven"). This especially requires reconciliation with God and forgiveness of sins, and a life in accordance with God's will - not under the tyranny of the Evil One. The concept of land is not mentioned in this prayer. The prayer is directed to God who is in heaven, and because it concerns God and his sovereignty, the perspective of the supplicant is much wider than a piece of land or one country. God cares for the earthly requirements; therefore the supplicant prays for this. This idea is stated in general, however, and is not focused on a locality. All bodily and material requirements are implied, like health, income, occupation, land, etc., but these are simultaneously placed in their relative position whilst the focus is placed on the kingdom of God.

\section{Conclusion}

When the personal factor with regard to the concept of land in the Old and the New Testament is fully taken into account, the following conclusions can be made:

- Ecclesiastically - a geographical bondage is excluded: locally, nationally (land), and universally. The dominating factor is a personal faith in God through Jesus Christ, and fellowship of the believers without exclusion, but with emphasis on the hearing and understanding of the gospel (everybody hearing the gospel in their own language, Acts 2). Being a church is not dependent on political independence.

- Politically - the believer is not redeemed from his people (or nation) but in his people, but he is simultaneously given a perspective transcending his people, a perspective in which his people, together with others, is servicable to Jesus Christ's universal, and even eschatological goal with the peoples. Scripture does not teach that only one people or group should live in one country, acquiring a land and possessing is of secondary importance and is subordinated to keeping the commandments: to love God and one's neighbour. 
- Socially and economically - all citizens should have the opportunity to share in the possession of the soil/land. Precautions should exist which protect the poor and unprotected in the land against exploitation so that the land can render security to everybody. Everybody, the poor and needy included, is responsible for working and keeping the soil and thus fighting poverty.

- Cosmically - every citizen has the duty to help safeguard the land against over-population, pollution and the annihilation of plants and animals, and to exercise positively their collective and individual calling of caring for the earth.

- Eschatologically - because of his sin man is a stranger on the earth. If one makes this discovery, he or she becomes deeply aware of the requirement for daily conversion. One's real citizenship exists in being in/by Christ, He who is the Mediator in heaven with God. Therefore Christians expect their real fatherland hereafter, on the new earth. They see all things in this perspective and subordinate them to this, remembering the words of Christ: "Seek first his kingdom and his righteousness, and all these things will be given to you" (Mat. 6:33). This command requires one to love God and one's neighbour, and includes caring for the earth/soil on which God "put" us.

\section{Bibliography}

BÄCHLI, O 1962. Israel und die Völker. Zurich : Zwingli.

BLENKINSOPP, J. 1986 Jahwe and other deities: conflict and accommodation in the religion of Israel. Interpretation, 40(4):366

BRINKMAN, J. 1992. The perception of space in the Old Testament. Kampen : Pharos

BRUEGGEMANN, W. 1978. The land: place as gift; promise and challenge in Biblical faith London: SPCK

CASTRO, E. 1991. Editorial. The Ecumemal Review, 43(1): 1-3.

CLEMENTS, R E. 1980 Isaiah and the deliverance of Jerusalem: a study of the interpretation of prophecy in the Old Testament. Sheffield : JSOT Press

DAVIES, W D. 1974. The Gospel and the land Los Angeles : University of California Press.

DU PLOOY, A. le R 1981. Kerkverband: 'n Gereformeerd-kerkregtelike studie. Potchefstroom PU for CHE (Th D -proefskrif)

EICHRODT, W 1967 Theology of the Old Testament. I London : SCM

ECUMENICAL REVIEW. 1991 43(1)

GERBRANDT, G.E. 1986. Kingship according to the Deuteronomistic history. Atlanta Scholars Press

FITZGERALD, M. 1991 Mission in Canberra International Review of Mission, 80(319 \& 320): 315-326.

GERLEMAN, G 1971 Jisra'el Israel (In THAT I München : Kaiser p 782-785)

GROSS, W 1988 Israel's hope for the renewal of the state Journal of Nomthiest Semuric Langrages, 14:101-133.

HAN, J.G. 1987. The restoration of Israel in covenam perspective an evegetical and revelation-historical study on the prophecies of the promise Porchefisroum lil for (IIf: (Th.D thesis.) 
HELBERG, J.L. 1988. The significance of the capacity of God as creator for his relationship to the land in the Old Testament. (In Sharon, M. ed. Pillars of smoke and fire: the Holy Land in history and thought. Papers delivered at the International Conference on the relations between the Holy Land and the world outside it. Johannesburg 1986. Johannesburg : Southern Book Publishers. p. 48-62)

HELBERG, J.L. 1990a. Die verbondsvolk se verhouding tot sy land. Potchefstroom : Dept of Central Publications, Potchefstroom University for Christian Higher Education

HELBERG, J.L. 1990b. Land in the Book of Lamentations. Zeitschift fur die alttestamentliche Wissenschafi, 102(3):372-385.

INTERNATIONAL REVIEW OF MISSION. 1991. 80(319 \& 320).

KAISER, W.C. Jr. 1981. The promised land: a Biblical view. Biblioteca Sacra, 138(549):302, 309-311.

KEIL, C F. 1949a. The First Book of Moses. Grand Rapids : Eerdmans.

KEIL, C.F. 1949b. The Second Book of Moses. Grand Rapids . Eerdmans.

KREUZER, S. 1983. Der lebendige Gott: Bedeutung, Herkunft und Entwicklung einer alttestamentlichen Gottesbezeignung. Stuttgart : Kohlhammer.

LEVENSON, J.D. 1976. Theology of the program of restoration of Ezekiel 40-48. Missoula Scholars Press

LEVENSON, J.D. 1985. Sinai and Zion: an entry to the Jewish Bible. Minneapolis : Winston Press.

LOHFINK, N. 1981. Hat Jesus eine Kirche gestiftet? Theologische Quartalschrifi, 161(2):8197.

MARTENS, E. 1972. Motivations for the promise of Israel's restoration to the land in Jeremiah and Ezekiel Claremont : Claremont Graduate School (Ph.D. thesis.)

NICHOLSON, E.W. 1986. God and his people; covenant and theology in the Old Testament. Oxford : Clarendon Press.

NOORT, E. 1995. 'Land' in the Deuteronom(ist)ic tradition. Genesis 15: the historical and theological necessity of a diacronic approach. (In De Moor, J.C. ed Synchronic or diacronic. Oud-lestamentische Studien, 34. Leiden : Brill. p. 129-144.)

OHLER, A. 1979 Israel, Volk und Land: zur Geschichte der wechselseitigen Beziehungen zwischen Israel und seinem Land in alttestamentlichen Zeit. Stuttgart : Katholisches Bibelwerk.

OLIVIER, J.H. 1996. Spatial awareness: an essential element of historical understanding in Old Testament studies. Old Testament Essays, 9(2):249-260.

OOSTERHOFF, B.J. 1973. De beloften aan de Aartsvaders. Kampen : Kok

PLOGER, O 1973. 'dmh. (In ThWAT. I Stuttgart : Kohlhammer. p. 95-105)

RAITT, T.M. 1977. A theology of exile: judgement/deliverance in Jeremiah and Ezekiel. Philadelphia : Fortress.

RENDTORFF, R. 1975 Israel und sein Land Theologische Uberlegungen zu einen Politischen Problem. Múnchen : Kaiser.

SANTMIRE, H P. 1985. The travail of nature: the ambiguous ecological promise of Christian theology. Philadelphia : Fortress.

STEGEMANN, H. 1983. 'Das Land' in der Tempelrolle und in anderen Texten aus den Qumranfunden (In Strecker, G. ed. Das Land Israel in biblischer Zeit. Jerusalem Symposium 1981 zu der Hebräischem Universität und der Georg-August Universität Gottingen : Vandenhoeck \& Ruprecht. p. 154-171.)

STEK, J 1978. Salvation, justice and liberation in the Old Testament Calvin Theological Journal, 13(2):133-165.

TERRIEN, S. 1978. The elusive presence: toward a new Biblical theology. New York Harper \& Row. 
TOWNSEND, J.L. 1985. Fulfilment of the land promise in the Old Testament. Biblioteca Sacra, 142(568):333-334.

VAN SELMS, A. 1967. Genesis II. Nijkerk : Callenbach.

VON RAD, G. 1968. Das Fünfte Buch Mose Deuteronomium. Gottingen : Vandenhoeck \& Ruprecht.

VRIEZEN, Th.C. 1966. Hoofdlijnen der theologie van het Oude Testament. Wageningen : Veenman.

WEINFELD, M 1993. The promise of the land: the inheritance of the land of Canaan by the Israelites. Berkeley : University of California Press.

WLDBERGER, H. 1956. Israel und sein Land. Evangelische Theologie, 16:404-405

WUDBERGER, H. 1982. Jesaja III. Neukirchen-Vluyn : Neukirchener Verlag

WRIGHT, J H. 1990. God's people in God's land: family, land, and property in the Old Testament. Grand Rapids : Eerdmans.

ZOBEL, H.J. 1982. jisra'el. (In ThWAT. III. Stuttgart : Kohlhammer. p. 986-1012.) 